\title{
СЛОВО НА ПЕРЕТИНІ ІДІОЛЕКТІВ: ІНТЕРТЕКСТУАЛЬНИЙ І МЕТАМОВНИЙ АСПЕКТИ (НА МАТЕРІАЛІ СПОГАДІВ МИХАЙЛИНИ КОЦЮБИНСЬКОЇ)
}

Трифонов Р. А. Слово на перетині ідіолектів: інтертекстуальний і метамовний аспекти (на матеріалі спогадів Михайлини Коцюбинської).

У статті на прикладі окремих лексем і лексикалізованих словосполучень показано, як елементи ідіолекту / індивідуального дискурсу Василя Стуса функціонують у «Книзі Споминів» Михайлини 
Коцюбинської, вводяться в текст метамовними засобами, співвідносяться зі змістом висловленого і встановлюють зв’язок між ідіолектами. Відзначено інтертекстуальну природу таких мовних знаків і їхню важливу роль у концептуалізації.

Ключові слова: ідіолект, інтертекстуальність, метамова, мовна особистість, мова шістдесятників.

Трифонов Р. А. Слово на пересечении идиолектов: интертекстуальный и метаязыковой аспекты (на материале воспоминаний Михайлины Коцюбинской).

В статье на примере отдельных лексем и лексикализированных словосочетаний показано, как элементы идиолекта / индивидуального дискурса Василя Стуса функционируют в «Книге Воспоминаний» Михайлины Коцюбинской, вводятся в текст при помощи метаязыковых средств, соотносятся с содержанием высказываний и устанавливают связь между идиолектами. Отмечены интертекстуальная природа таких языковых знаков и их важная роль в концептуализации.

Ключевые слова: идиолект, интертекстуальность, метаязык, языковая личность, язык шестидесятников.

Tryfonov R. A. Word on the Idiolects Intersection: Intertextual and Metalingual Aspects (on the memoirs of Mykhailyna Kotsyubynska).

The article, on the example of some lexemes and lexicalized word combinations, shows the ways how the elements of Vasyl Stus' idiolect / individual discourse function in «The Book of Memories» by Mykhailyna Kotsyubynska and are introduced into the text via metalingual means, correlate with the meaning of statements and establish interrelations between the idiolects. The stress is made upon the intertextual nature of such signs and their important role in the conceptualization.

Key words: idiolect, intertextuality, metalanguage, language personality, «people of the sixties» language.

У контексті важливого для сучасної лінгвістики зосередження на мовній особистості перебуває проблема свого і чужого слова, їх співіснування та співвідношення в дискурсі, функціональних аспектів. Останнім часом чимало праць, які грунтуються на здобутках світової філологічної думки, в українській лінгвістиці присвячені різноманітним виявам інтертекстуальності. У загальнотеоретичному мовознавчому вимірі інтертекстуальність розглядають О. Селіванова [10, с. 191-192], Н. Кондратенко [5], на матеріалі поезії - В. Калашник (його дослідження споріднюе з пропонованим мною увага до дискурсу шістдесятників [3]), О. Маленко [8, с. 407-414], на матеріалі публіцистики - В. Галич [1], сучасної преси - О. Рябініна [9]. Це лише частина студій у зазначеній галузі. Водночас про мовну природу інтертекстуальності варто говорити й далі, прискіпливо виявляючи, які саме мовні одиниці $є$ носіями інтертексту.

Про те, наскільки проблемним є останнє питання, свідчить хоч би й численність термінів, якими в наукових працях позначаються такі мовні знаки (доволі широкий перелік цих терміноодиниць подає Л. Дядечко [2, с. 20-21], при цьому сама дослідниця на додачу намагається відживити малопопулярне останнім часом поняття «крилаті слова», пропонуючи грецький відповідник «ептонім»). Між іншим, серед того переліку є й термін, який видається мені найбільш доречним 3 огляду на універсальність і системність, - інтертекстема (К. Сидоренко), його й прийму як робочий у цій статті. Однак проблема не лише в термінології, а й у визначенні суті досліджуваних мовних засобів.

Вихід на цю проблему пов'язаний із також не досить дослідженим явищем метамовного коментування в різноманітних типах текстів, зокрема в мемуарних. Серед видів метамовних коментарів, які можна виявити в 
спогадах різних людей, привертає увагу той, у якому мовець засвідчує належність лінгвальної одиниці до ідіолекту, дискурсу іншої людини. У разі, якщо в цьому простежуються ознаки не принагідності, а системності, це означає встановлення й експліцитне виявлення певних зв'язків між ідіолектами. Характер зв'язків такого типу та їхня природа не вивчені наразі в мовознавстві, як і способи їх репрезентації. 3'ясувати це й ставлю собі за мету в цій статті. А оскільки спостереження показало, що зазначене мовне явище виразно прослідковується в мемуарному творі Михайлини Коцюбинської «Книга Споминів» [6], саме цей текст і взято за матеріал.

Річ у тім, що «Книга Споминів» демонструє надзвичайно цікаві зв’язки між ідіолектами авторки і іiі побратима в справі та життєвій позиції- Василя Стуса. I ключовим мовним знаком, який дозволяє ці зв'язки встановити, є одиниця лексичного рівня - прямостояння. Ця інноваційна Стусова лексема має певний проміжний статус: вона не $є$ узуальною, але вже й не оказіональна; семантико-прагматичні особливості зумовили іiі перетворення з оказіоналізму спершу на ім'я ідіоконцепту як фрагмента картини світу митця, а відтак - на ім’я надперсонального концепту. (Аналізуючи оказіональні лексеми як засоби концептуалізації, В. Калашник використовує в ролі показового прикладу близьке до аналізованого тут Стусове слово самособоюнаповнення [4, с. 200-203].) Виникає цікава ситуація: концепт $є$ надперсональним, а його ім'я продовжує зберігати зв'язок із конкретною особистістю. Звідси маркованість, відображувана в метамовних коментарях, і у Михайлини Коцюбинської маємо різні ситуації з уведенням Стусової лексеми у свій авторський текст.

Природно, що відзначена мовна одиниця входить до тих контекстів, у яких авторка спогадів пише про самого Василя Стуса: «Погодилася розповісти про Стуса саме в Інституті, звідки його було брутально викинуто. <..> Хай почують про страдницький шлях свого колеги, який ходив з ними одними коридорами, пив з тих самих джерел, але зумів - на відміну від багатьох - вибороти собі поставу "прямостояння" (його вислів)» [6, с. 54-55]. 3 одного боку, лексичний знак можна розглядати як мінімальну (однослівну) інтертекстему в номінативній функції, як алюзію, для котрої коментар виконує функцію атрибуції. Але призначення виділеного комплексу «знак+коментар» насправді ширше - маркувати належність лексеми до оригінального Стусового ідіолекту i показати наявність відповідного концепту в Стусовій картині світу на рівні як лінгвальному, так і екстралінгвальному. Цікаво порівняти цей випадок із вельми подібним відсиланням до цієї ж мовної особистості: «Шлях нового, без оглядань $i$ табу, пізнавання й осмислення того, що Стус назвав «протрухлий украӥнський материк» [6, с. 34]. Як видається, з погляду мовної природи тут існує певна відмінність (хоч і часткова): надслівний знак в останньому випадку все ж належить радше до мовленнсвого рівня, 
натомість прямостояння можна означити як сталу одиницю внутрішнього словника, індивідуально маркований засіб рівня мови.

Щодо транспозиції імені концепту в ідіолект оповідачки слід відзначити, що це може бути показовим прикладом диференціації когнітивного і мовного рівнів, концептуальної і мовної картин світу. Адже до перейняття, запозичення слова Коцюбинською сам концепт у ії картині світу існував i, звичайно ж, існували певні засоби його вербалізації. Однак поява в тексті іншої людини цього мовного знака змусила визнати його найбільшу відповідність цьому концепту i надати, як видно 3 дискурсу авторки, статусу основного вербалізатора. А значущість концепту зумовила i значущість слова. Воно звучить в узагальненнях самої авторки щодо власного погляду на життя: «У різних проявах відчуваю ту життєдайну константу, яку поет назвав «прямостояння» $i$ «випростовування себе» [6, с. 104] (пор. слово константи на позначення головних концептів у класичній праці Ю. Степанова). Прикметним явищем, яке допомагає концептуалізувати поняття, $є$ ретроспективний метамовний коментар до слова: "...Найменшої тіні страху, пригнічення, «каші в роті» - ні в кого з родини я не відчувала. У мами і в тітки Насті завжди була гідна постава, спокійно гідна - не дозволяли нікому й ні в чому себе принизити, зігнути. У такій атмосфері $і$ я росла - неляканою. Не було ще Василевого слова прямостояння, але воно в мені жило - своєю суттю» [6, с. 175]. Це якраз і свідчить про те, що фрагмент концептуальної картини світу сформувався значно раніше за фрагмент мовної.

Узяте з ідіолекту однієї особистості слово може далі функціонувати на позначення рис інших людей, для творення їх образів: «B розмовах $з$ Борисом Антоненком-Давидовичем, щзо стосувалися особи й творчости Павла Григоровича [Тичини], я завжди мимоволі виступала в ролі захисника, намагалася якось пом'якиити суворі інвективи людини, яка, виборовши поставу прямостояння в житті, мала право й підстави до таких інвектив» [6, с. 187]. У цьому вияв надперсональності концепту 3 саме таким ім'ям. I нарешті, від рефлексії щодо рис близьких людей i власних світоглядних засад М. Коцюбинська переходить до введення слова в контекст, який стосується всього суспільства, - виходить, що вона інтерпретує його як елемент, котрий має належати загальнонаціональній картині світу: «Внутрішня свобода допомагає виробити прямоходіння й прямостояння, нормалізувати дихання. Відтак зростає суспільна цүінність індивіда, розвиваються його творчі потениії, зміцнюється громадянська дієздатність. Це особистість не втрачена для суспільства, a, навпаки, обернена до нього» [6, с. 263].

У метамовному аспекті привертає увагу неоднаковість атрибуції слова прямостояння в різних контекстах. Переважає в книжці загальна вказівка на особу Стуса, як уже було показано вище. Лише раз зустрічається деталізована атрибуція з наведенням фрагмента контексту, в якому вжито 
прецедентну одиницю: «Хоч $i$ не всі, але більшість витримала наступні випробування $i$ зуміла лишитися вірною тому «прямостоянню», щу, за висловом Василя у листі до Миколи Плахотнюка, «робить нас усіх братами» [6, с. 207]. Відчувається, що для Коцюбинської це слово переросло межі прототексту, воно репрезентує Стуса взагалі, і прецедентним феноменом $є$ тут уся його творчість, навіть більше - творчість у сукупності з життям, тобто індивідуальний дискурс. 3 іншого боку, оскільки слово прямостояння зустрічається в тексті «Книги Споминів» нерідко, постійний метамовний супровід тут не обов'язковий, тож частина вживань - безатрибутивні, напр.: «Людині посттоталітарної спільноти після десятиліть знеособлення, нав'язування комплексу «гвинтика», балансування між страхом (реальним) $i$ ентузіазмом (навіюваним), вироблення звички, щуо стала другою натурою, приховувати справжнє, питоме, своє $i$ розчинятися в колективній свідомості (чи несвідомості) - такій людині нелегко набути постави прямостояння» [6, с. 258].

Отже, у випадку з прямостоянням маємо мовний знак, що споріднює ідіолекти оповідачки і Стуса, позиціонує їхні світоглядні засади (він має ключову семантику для вербалізації системи поглядів людини), демонструє визнання однією людиною номінативної влучності іншої. Мовець (Коцюбинська) цілеспрямовано і самою дискурсивною практикою, і металінгвальними засобами експлікує свою дискурсивну солідарність із такою номінацією не стосовно якогось конкретного випадку, а в загальнішому вимірі, тобто йдеться не про мовленнєвий (як у багатьох випадках уживання алюзій), а про мовний рівень, навіть і про позамовний - ціннісний. Адже відбувається акцентування моментів не лише ідіолекту, а й системи цінностей, відображених у мовному знакові.

Про значущість концепту для Михайлини Коцюбинської свідчить наявність і ще однієї інтертекстеми, що вербалізує той самий ментальний фрагмент, але вже 3 металінгвальним відсиланням до прецедентного вислову іншої знакової мовної особистості: “Чуття гумору оздоровлює, очищує атмосферу, ставить речі з голови на ноги, допомагає поглянути на театр абсурду збоку - $і$ скласти всьому справжню иіну, відкинути сурогат $i$ розчистити душевний простір для непідробного. Ще раз утвердилася в изьому, ознайомивиись нещодавно зі щзоденниками Сергія Сфремова, з цим разючим документом епохи, свідченням людини, яка мала силу й мужність «самому стояти» (вислів Стефаника)» [6, с. 89].

Показово, що Стусова і Стефаникова інтертекстеми об'єднуються у фіналі книжки - у сильній текстовій позиції, що, за Е. Лассан, є свідченням когнітивної значущості концепту [7, с. 35-36]. Атрибуція наводиться, прототексти вже не стискаються до концентрованих знаків-репрезентантів, а подаються розлогіше:

«...Обстоювати тільки те, щуо стало внутрішнім переконанням, а не наспівано у вуха, хай які б наслідки для людини цуе мало. Вміти «стояти 
собі самому», як писав Стефаник: "...най єму кажуть, щзо продався $i$ «сподлився», лии би він стояв собі сам, бо так сму належиться». Чи не з таких «самотніх» осередків і твориться громадянське суспільство?!

I на закінчення - пронизливо точні слова Стуса, які я вже не раз повторювала:

$$
\begin{aligned}
& <\ldots> \\
& \text { Гріх - не боротися за себе } \\
& \text { і не випростувать себе. }
\end{aligned}
$$

Отже, «випростувать себе»...

Ефективнішого кредо я не знаю» [6, с. 274].

Тут, як і в одному з прикладів вище, наведено з поезії Василя Стуса інший репрезентант концепту ПРЯМОСТОЯННЯ, що має дуже важливу відмінність - процесуальну семантику, значення руху до бажаного стану.

Показово, що інші люди, які знали Михайлину Коцюбинську, відчувають значущість досліджуваного тут концепту для їі картини світу й акцентують це. У двох статтях на смерть цієї видатної людини, опублікованих поряд у газеті «День» за 11 січня 2011 р., можна це помітити. Мирослав Маринович, розгортаючи базову метафору, пише: «A щче ота особлива ї̈ риса, про яку вона сама згадала, виступаючи 2004 року перед випускниками Украӥнського католицького університету: «Внутрішня свобода допомагає виробити прямоходіння $i$ прямостояння...». Вона стояла так рівно і впевнено, щуо на неї багатьом легко було спертися, до неї прихилитися». А Дмитро Дроздовський вдається до метамовного коментування, що дозволяє створити виразний образ: «Боюся високих слів $і$ красивостей, але, на моє переконання, Михайлина Кочюбинська була людиною, орієнтованою на тотальне розуміння, якщо поряд із нею була також людина, яка знала сенс у слові «zідність»«. Тож концепт продовжує актуалізуватись у дискурсі зрештою, якраз для концепту ГІДНІСТЬ він $є$ субконцептом. Цікаво, що метафоричний зміст слова той-таки Мирослав Маринович у часописі «Критика» розгортає трохи по-іншому, але з неодмінним акцентом саме на цій лексемі: «У той знаменний день 4 вересня 1965 року у тому знаменному київському кінотеатрі «Украӥна» на заклик Івана Дзюби Михайлина Кочуюбинська сміливо встала - $i$ відтодi залишилася серед українців символом прямостояння» [http://krytyka.com].

Рідше в «Книзі Споминів» зустрічається ще один елемент Стусового дискурсу - слово щзопта. Та все ж і воно так само є ключовим для відгуку однієї особистості в семіосфері на слово іншої. Коцюбинська пише про Стуса і про себе: "...Його розум, «доброокість» $і$ чистота освітили й освятили той небезпечний шлях, на який я не могла не ступити. <...> Шлях, на якому відчувала себе причетною до чогось справжнього, до «маленької щзопти» людей гідних, які поняття «ідеал» сприймали екзистенційно» [6, с. 34]; «3а своїми літературно-мистецькими 
уподобаннями, за перекладацькими інтересами, за моральною позицією ми належали до одного кола, до однісї, Стусовими словами, «щопти» інтелектуального украӥнства, до «секти» шанувальників поетичної магії рідного слова» [6, с. 234]. Тут функція дискурсивної солідарності детермінована самою семантикою слова, котре і в Стуса, і в Коцюбинської має тотожне призначення - окреслення маленької спільноти, яка є дорогою для людини і до якої ця людина належить. Зрештою, навіть не лише на рівні семантики, а й у чистій референції ця щзопта у двох людей, напевно ж, в основному збігається. Не можу не відзначити, що в ході готування цієї статті я виявив відсутність цього слова - безперечно, знакового для української лінгвокультури, ключового для прецедентного i хрестоматійного тексту - у лексикографічних мегапроектах - «Великому тлумачному словнику сучасної української мови» у версії 2007 року і електронній базі «Словники України on-line» серед відповідно 250 і 256 тисяч слів... Але головне, що і це слово як ключове постає вже в текстах про саму Михайлину Хомівну, де в різних людей у межах невеликого фрагмента збігаються відсилання до обох слів на перетині ідіолектів Стуса i Коцюбинської. В Елеонори Соловей - назва тексту «Дух прямостояння», його початок: «...Бо - горстка нас. Малесенька щзопта - так мовив Василь Стус про коло найближчих по духу. Ще відтоді репресії, гоніння, просто час забирали одного по одному, тепер ось відійшла Михайлина Коияюбинська...». У Леоніда Плюща: «Михайлина належить до найсвітліших, того найкращуого, щуо було, скористаймося ї̈ ж словом, у русі прямостояння. Вона належала до «малесенької щзопти» тих, хто самим своїм існуванням повертали життя змертвілим $і$ спорожнілим словам, й самі породжували Слово «на вагу життя»« [http://krytyka.com обидва приклади].

Аналіз мемуарів Михайлини Коцюбинської показує, що номінативний знак, виразно запозичений 3 іншого ідіолекту, у своїй природі поєднує властивості стилістично маркованої лексеми (або лексикалізованого словосполучення: як номінативні, так i концептуалізаційні властивості цих двох типів знаків дуже близькі, що дозволяє варіювати форму, пор. щзопта - малесенька щзопта; прямостояння - самому стояти) й інтертекстеми, одиниці дискурсивного рівня. Завдяки явищам такого типу, як розглянуте в цій статті, текст перетворюється на щось більше за себе - на дискурс, він входить у певний простір, «семіотичний універсум» [10, с. 191], де реалізовуються зв’язки між текстами й між особистостями їх творців. Але потенційно такі зв'язки широкі, тож їх метамовна експлікація акцентує вибір мовця, а отже - його самопозиціонування в дискурсі. I настільки цілеспрямована експлікація, як у розглянутому випадку, свідчить про важливість такого самопозиціонування. Аналіз різних способів та шляхів останнього $\epsilon$ перспективним напрямом дослідження. 


\section{Література}

1. Галич В. М. Поетика публіцистичного тексту (на матеріалі творчості Олеся Гончара) / Валентина Галич. - К. : Шлях, 2006. - 200 с.

2. Дядечко Л. П. «Крылатый слова звук», или Русская эптология / Л. П. Дядечко. - К., 2006. - 336 с.

3. Калашник В. С. Інтертекстуальність як стилетвірний чинник у поемах Івана Світличного // Калашник В. С. Людина та образ у світі мови : вибрані статті / Володимир Калашник. - Х., 2011. C. 221-226.

4. Калашник В. С. Оказіональне словотворення як спосіб концептуалізації художнього світу поета (за ідіостилями Василя Стуса, Миколи Вінграновського, Степана Сапеляка) / Володимир Калашник // Там само. - С. 200-206.

5. Кондратенко Н. Категорія інтертекстуальності в сучасній українській мові / Наталя Кондратенко // Наук. вісн. Чернівецького ун-ту. - 2009. - Вип. 475-477 : Слов. філологія. - С. 552-556.

6. Коцюбинська М. Х. Книга Споминів / Михайлина Коцюбинська. - Х. : Акта, 2006. - 288 с.

7. Лассан Э. Лингвокультурология : очерк русской концептологии / Элеонора Лассан. - Vilnius : Vilniaus ped. un-to leidykla, 2008. - $140 \mathrm{c}$.

8. Маленко О. О. Лінгво-естетична інтерпретація буття в українській поетичній мовотворчості (від фольклору до постмодерну) / Олена Маленко. - Харків : Харк. іст.-філол. т-во, 2010. - 488 с.

9. Рябініна О. К. Інтертекстуальність у дискурсі сучасної української преси: лінгвістичний аспект : дис. ... канд. філол. наук за спец. 10.02.01 - українська мова / О. К. Рябініна. - Х., 2007. - 215 с.

10. Селіванова О. О. Сучасна лінгвістика : термінологічна енциклопедія / Олена Селіванова. Полтава : Довкілля-К, 2006. - 716 с.

Стаття надійшла до редакції 17.11.2011 р. 